\title{
PENILAIAN KINERJA KEPALA SEKOLAH DAN GURU MUHAMMADIYAH
} KECAMATAN TEMPEL

\author{
Dedy Setyawan ${ }^{1}$, Muhammad Zuhaery ${ }^{2}$ \\ ${ }^{1,2}$ Manajemen Pendidikan, Universitas Ahmad Dahlan \\ ${ }^{1}$ Email: setyawandedy02@gmail.com \\ ${ }^{2}$ Email: muhammadzuhaery@gmail.com
}

\begin{abstract}
ABSTRAK
Tujuan penelitian: (1) mengukur penilaian kinerja kepala sekolah (2) mengukur penilaian kinerja guru (3) mengetahui hubungan penilaian kinerja kepala sekolah terhadap penilaian kinerja guru. Penelitian ini merupakan deskriptif kuantitatif. Responden penelitian ini 9 kepala sekolah dan 41 guru yang sudah bersertifikasi. Teknik pengumpulan data yang digunakan angket dan dokumentasi. Berdasarkan hasil penelitian dengan kategori baik ditunjukan sebagai berikut: (1) kompetensi kepribadian dan sosial 65\% kategori baik (2) kompetensi kepemimpinan 62\% kategori baik (3) kompetensi pengembangan sekolah $64 \%$ kategori baik (4) kompetensi sumber daya $61 \%$ kategori baik (5) kompetensi kewirausahaan 59\% kategori baik (6) kompetensi supervisi pembelajaran dengan 55\% kategori baik. Hasil penilaian kepala sekolah dengan kategori baik. Penilaian kinerja guru dengan hasil sebagai berikut; (1) kompetensi pedagogik 65\% kategori baik (2) kompetensi kepribadian 64\% kategori baik (3) kompetensi sosial 69\% kategori baik (4) kompetensi professional $60 \%$ kategori baik.
\end{abstract}

Kata Kunci: Penilaian, kinerja kepala sekolah, kinerja guru, SD Muhammadiyah

\begin{abstract}
The research objectives: (1) measure the performance appraisal of the principal (2) measure the teacher's performance appraisal (3) determine the relationship between the principal's performance appraisal and the teacher's performance appraisal. This research is a quantitative descriptive. Respondents in this study 9 principals and 41 teachers who have been certified. Data collection techniques used questionnaires and documentation. Based on the results of research with good categories, it is shown as follows: (1) personality and social competence 65\% good category (2) leadership competence $62 \%$ good category (3) school development competence $64 \%$ good category (4) resource competence $61 \%$ good category (5) entrepreneurial competence $59 \%$ good category (6) learning supervision competence with 55\% good category. The results of the principal's assessment are in the good category. Teacher performance assessment with the following results; (1) pedagogic competence $65 \%$ good category (2) personality competence $64 \%$ good category (3) social competence $69 \%$ good category (4) professional competence $60 \%$ good category.
\end{abstract}

Keywords: Assessment, principal's performance, teacher's performance, Muhammadiyah Elementary School

\section{PENDAHULUAN}

Kinerja guru merupakan hal yang sangat penting untuk menilai dan mengoreksi antara kemajuan dari guru beserta sekolah tersebut, dengan demikian kinerja guru sangatlah diperlukan (Ariyadi \& Rohmah, 2019). Menurut (Afifah, 2019) penilaan kinerja guru dilakukan oleh kepala sekolah melalui beberapa penilaian antara lain penilaan sikap, 
profesional, pedagodik, sosial, dan empat kompetensi ini haruslah bisa dikuasai oleh guru dimanapuan berada. Sesuai dengan pendapat (Firman \& Pitaloka, 2021) maka dpat disimpulkan bahwa adanya peningkatan kompetensi guru akan mengubah kondisi baik guru maupun sekolah tersebut.

Selanjutnya, menurut (Ali \& Hasanah, 2021) peran kepala sekolah sebagai manajer, pimpinan pengajar dan supervisor, pencipta iklim yang kondusif, administrator, coordinator kerja sama dalam masyarakat dan yang sering dilupakan ialah sebagai panjang tangan pengurus. Peran yang terakhir dari kepala skeolah ini bertujuan untuk mempunyai persepsi yang sama dengan pengurus dalam hal mengelola sekolah, sehingga visi dan misi sekolah dapat terlaksana dilapangan (Dwikoranto, 2018). Maka, sesuai dengan pendapat (Hartanto \& Sumardjoko, 2018) bahwa dalam mengelola sekolah, kepala sekolah memiliki peran yang sangat besar. Kepala sekolah merupakan motor pengerak, penentu arah kebiajakan menuju sekolah dan pendidikan secara luas (Oktafiani \& Harsono, 2019). Sebagai pengelola institusi sebuah pendidikan, kepala sekolah dituntut untuk selalu meningkatkan efektifitas kinerjanya (Tarmo \& Sumardjoko, 2019). Untuk mencapai mutu sekolah yang efektif, kepala sekolah dan seluruh stakeholders harus bahu membahu bekerjasama dengan penuh kekompakan dalam segara hal (Djafar \& Nurhafizah, 2018).

Kepala sekolah, sebagai manajer mampu bekerja dengan orang lain atau melalui wakil-wakilnya, serta berusaha untuk senantiasa mempertanggungjawabkan setiap tindakan dan mampu menghargai berbagai persoalan di sekolah (Septian \& Sumardjoko, 2021). Untuk itu kepala sekolah dapat membimbing dan mengarahkan seluruh program pengajaran serta melakukan pengawasan dalam pelaksanaan dalam proses pengembangan program sekolah dan kebutuhan peserta didik (Nisda, 2019).

Sekolah Dasar Muhammadiyah yang ada di Kecamatan Tempel, merupakan sekolah dasar yang megedepamkan kualitas, kepribadian, serta prestrasi. Kegiatan tidak akan berjalan dengan baik, apabila tidak ditunjang oleh semua elemen sekolah, termasuk guru dan kepala sekolah dalam menata sekolah kearah yang lebih baik (Anggini \& Suwarno, 2018). Menurut (Gultom, 2018) peran kepala sekolah dalam administrasi pembelajaran di sekolah dasar di Kecamatan Tempel sangat diperlukan dalam rangka mencapai tujuan yang telah ditetapkan. Hal ini dapat diletakkan melalui proses perencanaan, pengorganisasian, pengarahan, pengkoordinasian, pembiayaan, pengendalian, penilaian serta pendayagunaan seluruh sumber daya sekolah termasuk guru (Nofiyanti, 2015).

Kecamatan Tempel terdapat 34 sekolah yang terdiri dari: sekolah dasar negeri ada 20, Sekolah Dasar Muhammadiyah ada 10, Madrasah Ibtidaiyah atau MI ada 4. Sekolah 
muhammadiyah di Kecamatan Tempel selama ini selalu ungul dalam bidang akademik kelulusan. Disamping itu pula guru atau tenaga pengajar yang ada di sekolah muhammadiyah juga mempunyai kompetensi yang sangat bagus yang tidak kalah dengan sekolah negeri, bahkan kebanyakan guru muhammadiyah mempunyai kompetensi yang lebih bagus. Jumlah guru keseluruhan di Kecamatan Tempel ada 319 terdiri dari guru PNS ada 198 guru Non PNS ada 121. Untuk guru yang di sekolah Muhammadiyah terdiri dari 27 Guru PNS dan 81 Guru Non PNS, untuk sekolah negeri 171 Guru PNS dan 40 Guru Non PNS. Sedangkan guru laki laki berjumlah 101 dan perempuan berjumlah 218. Sekolah Muhammadiyah yang memiliki sertifikat pendidik antara lain 9 kepala sekolah terdiri dari 3 laki-laki, dan 6 perempuan, sedangkan guru yang sudah mempunyai sertifikat pendidik ada 41 guru bersertifikat pendidik.

Sekolah Muhammadiyah di Kecamatan Tempel merupakan sekolah yang sangan disukai dan diminati oleh masyarakat, dengan dibuktikan bahwa sekolah muhammadiyah selalu mempunyai jumlah siswa yang sangat banyak di bandingkan sekolah negeri atau sekolah swasta yang lainya. Disamping itu, sekolah muhammadiyah selalu memasuki peringkat yang memuaskan di Kecamatan Tempel, selalu masuk ke dalam sepuluh besar peringkat sekolah yang mempunyai kelulusan dan prestasi yang unggul, selain itu sekolah muhammadiyah di Kecamatan Tempel juga pernah meraih juara atau prestasi di tingkat kabupaten dalam nilai ujian nasional.

Salah satu masalah yang dihadapi kepala sekolah di Kecamatan Tempel dalam meningkatkan kinerja guru sekolah dasar muhammadiyah adalah penilaian kinerja guru oleh kepala sekolah secara berkala masih belum terlaksana dengan baik dan terstruktur. Dengan demikian kinerja guru merupakan salah satu faktor dalam meningkatkan visi dan misi sekolahan belum sesuai dengan yang diharapkan. Sedangkan masalah kepala sekolah dalam mengembangkan program kerjanya selalu terkendala dalam pengorganisasian dan koordinasi dengan guru yang menyebabkan program tidak berjalan dengan lancar sesuai harapan. Masalah tersebut diambil dari hasil pengamatan serta melihat dokumen pendukung seperti catatan kegiatan dan hasil PKG.

Kepala sekolah sebagai pemimpin sangatlah berpengaruh terhadap perkembangan sekolah, dengan demikian kepala sekolah diharapkan bisa menguasai 6 kompetensi yaitu: kompetensi kepribadian dan sosial, kompetensi kepemimpinan dan pengembangan, kompetensi pengembangan sekolah, kompetensi sumber daya, kompetensi kewirausahaan, dan kompetensi supervisi pembelajaran. Guru merupakan pendidik dan pengembang di sekolah, jadi guru juga mempunyai peran kinerja yang penting. Dalam meningkatakan 
peran guru diharapkan bisa menguasai 4 kompetensi yaitu: kompetensi pedagogik, kompetensi kepribadian, kompetsni sosial dan kompetsni professional. Jadi peran kepala sekolah dan guru sama-sama penting, keduanya tidak bisa dipisahkan.

\section{METODE PENELITIAN}

Jenis penelitian ini adalah deksriptif kuantitatif, berdasarkan Arikunto, (2002, hlm. 10) metode kuantitatif bertujuan untuk mengumpulkan data penelitian, menafsirkan data penelitian, menampilkan hasil penelitian, menggunakan angka dalam penelitian. Penelitian ini bertujuan untuk mengetahui penilaian kinerja kepala sekolah dan guru muhammadiyah di Kecamatan Tempel. Penelitian ini dilakukan pada Sekolah Dasar Muhammadiyah yang terletak di Kecamatan Tempel Kabupaten Sleman pada tahun pelajaran 2020/ 2021.

\section{Populasi dan Sampel Penelitian}

Populasi pada penelitian ini adalah kepala sekolah yang berjumlah 10 orang kepala sekolah dan 116 orang guru yang terdiri dari guru PNS dan guru Non PNS, dari 10 sekolah Muhammadiyah di Kecamatan Tempel Sleman. Menurut Sugiono, (2016, hlm 148) populasi adalah wilayah generalisasi yang terdiri dari obyek/ subyek yang mempunyai kuantitas dan karateristik tertentu yang ditetapkan oleh peneliti untuk dipelajari dan kemudian ditarik kesimpulan. Peneliti mengambil 9 sekolah dari 10 sekolah dasar Muhammadiyah di Kecamatan Tempel untuk penelitian dikarenakan 1 sekolah merupakan tempat peneliti bekerja sehingga tidak bisa dijadikan sebagai subyek penelitian.

Sampel adalah bagian dari karakteristik yang dimiliki oleh populasi. Sampling Purposive adalah teknik pengambilan sampel dengan pertimbangan tertentu dengan tidak melakukan generalisasi, menurut Sugiono, (2016, hlm 156). Melihat sampel yang sangat besar, penelitian ini menggunakan teknik pengambilan sampel menggunakan Sampling Purposive. Sampel dalam penelitian ini adalah semua guru yang sudah bersertifikat pendidik, berjumlah 41 guru dan 9 kepala sekolah baik PNS maupun Non PNS.

\section{Variabel Penelitian}

Variabel penelitian adalah sesuatu yang dapat digunakan dan dikembangkan serta bisa diteliti. Variabel independen atau biasa disebut dengan variabel bebas, sedangkan variabel dependen atau biasa disebut dengan variabel terikat menurut (Sugiono, 2016, hlm. 95). Kinerja kepala sekolah merupakan pondasi yang pokok dalam pengelolaan sebuah sekolah, sehingga berperan sangat penting dan berpengaruh dalam keberlangsungan penyelenggaraan pendidikan. Unsur dari kepala sekolah ada 6 yaitu kepribadian sosial, 
kepemimpinan, pengembangan sekolah, pengelolaan sumber daya, kewirausahaan, dan supervisi. Guru merupakan penyanding dan pembantu keberlangsungan dari suatu pendidikan, maka dari itu guru juga berperan sangat penting dalam pendidikan. Guru mempunyai 4 unsur yang tidak dapat dipisahkan yaitu pedagogik, kepribadian, sosial dan professional.

\section{Teknik dan Instrumen Pengumpulan Data}

Teknik pengumpulan data menurut Sugiono, (2016, hlm. 223-224) pengumpulan data dapat dilakukan dengan berbagai sumber yang tepat, adapun teknik pengumpulan data adalah interview (wawancara), kuesioner (angket), observasi (pengamatan), dan gabungan ketiganya. Menurut Arikunto, (2010, hlm. 101) teknik pengumpulan data dalam penelitian, dapat dilakukan dengan menggunakan angket (questionnaire), wawancara atau interviu (interview), pengamatan (observation), ujian atau tes (test), dokumentasi (documentation), dan lain sebagainya. Penelitian ini menggunakan teknik pengumpulan data dengan angket dan dokumentasi. Angket digunakan sebagai data utama dalam penelitian ini, sedangkan dokumentasi sebagai data pendukung dalam penelitian ini. Untuk lebih jelas dapat diuraikan sebagai berikut.

Penelitian ini menggunakan angket sebagai pengumpulan data. Dalam penelitian ini angket ditujukan kepada 9 kepala sekolah dan 41 guru yang ada di Kecamatan Tempel. Menurut Sugiyono (2016, hlm 230), angket merupakan teknik pengumpulan data yang dilakukan dengan cara memberi seperangkat pertanyaan atau pernyataan tertulis kepada responden untuk dijawabnya. Angket yang digunakan dalam penelitian ini yaitu, berupa angket tertutup dengan alternatif jawaban yang sudah tersedia. Peneliti menggunakan angket sebagai teknik utama dalam pengumpulan data karena lebih efektif dan cepat diperoleh data. Model angket dalam penelitian berbentuk google form, yang dibagikan melalui watshapp kepada kepala sekolah dan guru.

Metode dokumentasi adalah "suatu teknik pengumpulan data dengan menghimpun dan menganalisis dokumen-dokumen, baik dokumen tertulis, gambar maupun elektronik”. Metode dokumentasi merupakan telaah sistematis atau catatan-catatan dan dokumendokumen sebagai sumber data, baik berupa kalimat tertulis, grafik, gambar lukisan, dan beda-benda lain yang bersifat verbal. Dokumentasi diperlukan sebagai alat pengumpul data, serta digunakan untuk mencari data-data yang berbentuk teori-teori pendidikan, saerana dan prasarana sekolah, data latar belakang pendidikan guru, data siswa yang meliputi laporan, hasil evaluasi, jumlah siswa, prestasi siswa dan sebagainya. Dokumentasi yang berbentuk teori-teori pendidikan yang dimaksud adalah mencakup buku-buku tentang 
pendidikan dan yang terkait dengan peran kepala sekolah, administrasi pendidikan serta pembelajaran pada khususnya. Pengambilan dokumen dalam penelitian ini dengan cara memfoto dokumen pelaksanaan PKG, Kurikulum Sekolah dan dokumen lain yang diperlukan menurut Sukmadinata (2006, hlm. 221).

Instrument adalah alat yang digunakan untuk mempermudah seseorang dalam menyelesaikan tugas dengan efektif dan efisien. Instrument yang digunakan dalam penelitian ini adalah menggunakan angket untuk mengukur penilaian kinerja kepala sekolah dan guru Muhammadiyah di Kecamatan Tempel. Dokumentasi digunakan sebagai data pendukung dalam penelitian ini supaya lebih sempurna. Dalam penyusunan anket sudah disesuaikan dengan data teoritik yang sudah ada kemudian dikembangkan berdasarkan dengan indikator dan dijabarkan dalam butir pertanyaan menurut Arikunto (2013, hlm. 40).

Dalam pengukuran dan memperjelas dalam penyusuan instrument penelitian, maka perlulah dibuatkan sebuah kisi-kisi instrument supaya lebih terarah. Kisi-kisi instrument penilaian kinerja kepala sekolah dengan 6 sub variabel yang dijabarkan menjadi 6 indikator kemudian diuraikan lagi menjadi 40 butir pertanyaan yang akan digunakan dalam penelitian. Kisi-kisi instrument penilaian kinerja guru terdapat 4 sub variabel, yang dijabarkan menjadi 14 indikator, kemudian diuraikan lagi menjadi 78 butir pertanyaa yang akan digunakan dalam penelitian.

Pengukuran yang digunakan dalam pembuatan instrumen penelitian ini menggunakan skala penilaian untuk mempermudah dalam penilaian dan pengolahan hasil dari responden. Skala yang digunakan dalam penilaian ini adalah skala liker. Menurut Sugiono (2016, hlm. 168) skala liker dapat digunakan untuk mengukur sikap, pendapat, dan persepsi seseorang atau kelompok orang tentang fenomena sosial yang nantinya akan disebut sebagai variabel. Indikator variabel akan dijabarkan menjadi tolok ukur menyusun butir pertanyaan yang bisa berbentuk pertanyaan atau pernyataan.

Skala liker adalah berupa pertanyaan atau pernyataan yang jawabanya berupa skala deskriptif ataupun skala garis yang dikemukan oleh Sukmadinata (2010, hlm. 230). Dengan demikian skor yang digunakan untuk mengukur variabel yang dijabarkan menjadi butir-butir pertanyaan dengan penjabaran secara deskriptif. Pemberian skor diperuntukan untuk mengetahui seberapa besar kemampuan atau ketercapaian yang diperoleh kepala sekolah dan guru dalam melaksanakan kegiatan. Skor paling tinggi 4 (empat) dan paling rendah 1(satu). Jadi skor yang digunakan untuk menjawab butir-butir pertanyaan menurut (Sugiono, 2016, hlm. 169). 


\section{Validitas dan Reliabilitas Instrumen}

Untuk mengetahui kualitas instrumen akan dilakukan uji validitas dan uji reliabilitas instrumen. Menurut Arikunto (2010 hlm. 167) menjelaskan bahwa "validitas adalah keadaan yang menggambarkan tingkat instrumen yang bersangkutan mampu mengukur apa yang akan diukur". Menurut Nana Syaodih Sukmadinata (2006, hlm. 229), validitas isi berkenaan dengan isi dan format dari instrumen, apakah instrumen tepat mengukur hal yang ingin dikukur, apakah butir-butir pertanyaan telah mewakili aspekaspek yang akan diukur, apakah pemilihan format instrumen cocok untuk mengukur segi tersebut.

\section{Uji Validitas Instrumen}

Uji validitas adalah suatu alat yang menunjukkan seberapa jauh suatu instrumen memiliki ketepatan dan kecermatan dalam melakukan fungsi ukurnya. Arikunto (2006, hlm. 168-169) menyampaikan bahwa tinggi rendahnya validitas instrumen menunjukkan sejauh mana data yang terkumpul tidak menyimpang dari gambaran tentang variabel yang dimaksud.

Dalam menguji validitas konstruksi dapat digunakan pendapat dari para ahli. Para ahli akan diminta pendapatnya tentang instrument yang telah disusun. "Mungkin para ahli akan memberi keputusan instrument dapat digunakan tanpa perbaikan, ada perbaikan, dan mungkin dirombak total" menurut Sugiono (2016, hlm. 207).

Pengujian validitas butir instrument setelah dikonsultasikan kepada para ahli akan diujicobakan kepada instrument yang sama. Dalam menguji validitas setiap butir intrumen digunakan analisis dengan rumus korelasi product moment dari pearson.

Analisis faktor dilakukan dengan cara mengkorelasikan jumlah skor faktor dengan skor total, bila korelasi tiap faktor diperoleh dengan besaran 0,3 ke atas maka dapat dikatan faktor tersebut kuat, serta dapat dikatakan validitas konstruksi yang baik menurut Sugiono (2016, hlm. 208). Pengujian validitas instrument menggunakan aplikasi SPSS-21.

Dalam penelitian ini dilakukan uji validitas instrument yang dilakukan kepada 9 kepala sekolah dan 41 guru sekolah dasar Muhammadiyah di Kecamatan Tempel. Berdasarkan dari uji instrumen di jelaskan, bahwa hasil instrument kepala sekolah dengan jumlah 40 butir instrument dinyatakan valid dan dapat digunakan untuk penelitian. Hasil validitas instrument kepala sekolah berdasarkan dengan table di atas yang dianalisis menggunakan summary menyatakan bahwa dari $\mathrm{N}=9$ dengan presentase $100 \%$, dengan demikian dapat dikatakan valid. Berdasarkan dari uji instrumen di jelaskan bahwa, hasil 
instrument guru dengan jumlah 78 butir instrument dinyatakan valid dan dapat digunakan untuk penelitian.

Hasil validitas instrument guru berdasarkan dengan analisis menggunakan summary menyatakan bahwa dari $\mathrm{N}=41$ dengan presentase $100 \%$, dengan demikian dapat dikatakan valid. Berdasarkan dari uji validitas instrumen di atas, bahwa hasil instrument kepala sekolah yang berjumlah 40 butir pertanyaan dan guru yang berjumlah 78 butir pertanyaan dinyatakan valid dan dapat digunakan untuk penelitian. Dengan demikian peneliti bisa menggunakan instrument untuk penelitian.

\section{Uji Reliabilitas}

Selain harus valid, instrumen juga harus memenuhi standar reliabilitas. Suatu instrumen dikatakan reliabel jika dapat dipercaya untuk mengumpulkan data penelitian. Menurut Arikunto (2006, hlm. 178) menyatakan bahwa reliabilitas menunjukkan pada suatu pengertian bahwa suatu instrumen cukup dapat dipercaya untuk digunakan sebagai alat pengumpul data karena instrumen tersebut sudah cukup baik.

Suatu hasil pengukuran dapat dikatakan reliabel jika alat pengukur tersebut dapat dipercaya, sehingga mendapatkan hasil yang tetap dan konsisten. Pada penelitian ini instrumen penelitian akan dianalisis dengan bantuan aplikasi komputer program SPSS. Metode yang digunkan dalam uji reliabilitas penelitian ini adalah metode Cronbach's Alpha untuk mengetahui akuratnya alat ukur yang digunakan.

Bukti instrument diuji menggunakan SPSS 21. Hasil pengujian reliabilitas menggunakan Cronbach'a Alpha diperoleh hasil total sebesar 0.987 untuk kepala sekolah, sedangkan untuk guru diperoleh hasil total sebesar 0,972, nilai tersebut dapat dinyatakan valid. Dengan demikian angket yang digunakan untuk mengukur kinerja kepala sekolah dan guru sekolah dasar muhammadiyah di Kecamatan Tempel dinyatakan reliabel dan dapat digunakan sebagai alat pengumpulan data.

\section{Teknik Analisis Data}

Analisis data adalah mengelompokan data berdasarkan variabel dan jenis responden, mentabulasi data berdasarkan variabel dari seluruh responden, menyajikan data tiap variabel yang diteliti, dan melakukan perhitungan untuk menjawab rumusan masalah menurut Sugiyono (2011, hlm. 402). Teknik analisis data yang digunakan dalam penelitian ini adalah analisis deskriptif kuantitatif. Setelah mendapatkan rumus analisis data, kemudian hasil dideskripsikan berdasarkan dengan kategori skor penilaian. Hal ini akan 
digunakan untuk mengetahui kinerja kepala sekolah dan guru sekolah dasar Muhammadiyah di Kecamatan Tempel.

\section{HASIL DAN PEMBAHASAN}

Penilaian kinerja kepala sekolah dasar muhammadiyah di Kecamatan Tempel yang memuat 6 standar kompetensi antara lain kompetensi kepribadian sosial, kompetensi kepemimpinan, kompetensi pengembangan sekolah, kompetensi pengelolaan sumber daya, kompetensi kewirausahaan, kompetensi supervisi. Dari 6 standar yang dilakukan kepala sekolah hasil penelitian kompetensi yang masih rendah adalah supervisi kepala sekolah dengan presentase $55 \%$.

Kepribadian dan sosial kepala sekolah dapat di peroleh hasil skor 204 dengan presentase $65 \%$ dengan kategori baik. Berdasarkan hasil penelitian dari 9 responden diperoleh hasil perolehan skor tertinggi yaitu 28 dan terendah yaitu 17. Kepemimpinan kepala sekolah dapat di peroleh hasil skor 208 dengan presentase yang di dapat $62 \%$ dengan kategori baik. Hasil presentase masih ada 4 kepala sekolah yang di bawah $62 \%$ walaupun dengan kategori baik. Dengan nilai skor tertinggi yang diperoleh adalah 39 dan skor terendah 22.

Pengembangan sekolah dapat diperoleh skor 201 dengan hasil presentase yang diperoleh 64\% dengan kategori baik. Dari hasil penelitian yang diperoleh didapatkan bahwa skor teretinggi dengan jumlah 28 dan skor terendah yang di dapat adalah 16 . Berdasarkan hasil penelitian didapatkan 4 kepala sekolah masih di bawah 64\% peresentasenya dengan begitu keempat kepala sekolah ini perlu mendapatkan pendampingan dalam kegiatan pengembangan sekolah.

Kompetensi pengelolaan sumber daya kepala sekolah dengan perolehan skor 219, hasil presentase $61 \%$ dengan kategori baik. Dilihat dengan hasil penelitian bahwa pengembangan sumber daya kepala sekolah diperoleh dengan nilai tertinggi 31, dan nilai terendah yang di dapat adalah 18. Hasil penelitian menyatakan bahwa masih ada empat kepala sekolah yang di bawah $61 \%$ jadi belum mencapai target.

Kewirausahaan dengan perolehan skor 132, dengan presentase perolehan 59\% dan kategori baik. Berdasarkan dengan hasil penelitian berkenaan dengan kewirausahaan dapat diperoleh dengan skor tertinggi adalah 20 dan nilai terendah yang diperoleh adalah 10 . Supervisi kepala sekolah Muhammadiyah Kecamatan Tempel dengan perolehan skor 74 dengan presentase $55 \%$, kategori baik. 
Berdasarkan dengan data yang diperolah bahwa hasil kompetensi guru yang masih rendah adalah kompetensi professional guru dengan presentase $60 \%$ dengan kategori baik. Hasil penyebaran instrument kepada 41 guru sekolah dasar Muhammadiyah di Kecamatan Tempel dapat dijabarkan sebagai berikut.

Kompetensi pedagogik, dengan perolehan skor 6.005, presentase $65 \%$ dengan kategori baik. Kompetensi kepribadian guru yang mendapatkan skor perolehan 2.345, predentase $64 \%$, dengan hasil kategori baik. Kompetensi kepribadian berdasarkan dengan hasil penelitian dengan kategori baik untuk 41 reponden guru dengan presentase yang diperoleh 64\%. Presentase yang diperoleh dalam kepribadian guru dapat dijabarkan sebagai berikut, terdapat 19 responden guru masih di bawah 64\% dengan kategori baik, sedangkan ada 22 responden mendapatkan presentase di atas 64\%. Hamper sebagian responden belum memenuhi kriteria sebagai guru yang berkompeten.

Kompetensi sosial, hasil yang diperoleh dalam penelitian dengan perolehan skor 854, dengan presentase $69 \%$ dan kategori yang di dapat adalah baik. Hasil tentang kepribadian sosial guru dengan responden 41 diperoleh kategori baik untuk 41 responden, dengan presentase 69\%. Adapun responden yang masih mendapatkan presentase di bawah 69\% ada 14 guru, sedangkan 27 guru mendaptkan presentase di atas $69 \%$.

Kompetensi professional dengan hasil perolehan skor 1.111, presentase 60\%, dan kategori yang di dapat adalah baik. Hasil penelitan dengan penyebaran angket diperoleh bahwa masih ada 1 responden dengan kategori cukup, sedangkan 40 responden dengan kategori baik, presentase yang diperoleh $60 \%$. Responden dengan hasil presentase di bawah $60 \%$ ada 19 dan yang mendapatkan presentase di atas $60 \%$ ada 22 responden.

Hasil pengamatan tentang hubungan penilaian kinerja kepala sekolah dan penilaian kinerja guru tidak ada keterkaitan namun saling melengkapi. Merujuk pada Peraturan Menteri Pendidikan Nasional Nomor 28 Tahun 2010 Pasal 12 tentang Penugasan Guru sebagai Kepala Sekolah/Madrasah menyatakan bahwa guru yang diberi tugas tambahan sebagai kepala Sekolah/ Madrasah dinilai kinerjanya secara berkala setiap tahun dan secara kumulatif selama 4 tahun yang akan dijadikan dasar bagi promosi atau demosi yang bersangkutan.

Kemudian untuk mendukung kinerja guru dapat mengacu pada Permendiknas No. 41/2007 tentang Standar Proses Pendidikan, yaitu standar nasional pendidikan yang berkaitan dengan pelaksanaan pembelajaran pada satuan pendidikan. Standar proses meliputi tugas-tugas pokok yang harus dilaksanakan oleh guru seperti: (1) Perencanaan proses belajar, (2) Pelaksanaan proses pembelajaran, (3) Penilaian hasil pembelajaran, dan 
(4) Pengawasan proses pembelajaran. Jadi, tugas-tugas pokok yang harus dilaksanakan guru meliputi perencanaan, proses, dan penilaian hasil pembelajaran.

Dari sinilah peneliti mengambil kesimpulan bahwa penilaian kinerja kepala sekolah dan penilain kinerja guru ada keterkaitan namun tidak ada pengarunya berkaitan dengan ketugasannnya yang mengacu dan melihat hasil hipotesis penelitian ini. Tidak adanya keterkaitan dalam penilain kepala sekolah dan penilaian kinerja guru menurut peneliti disebabkan dalam proses pengambilan data instrument ada ketidak jujuran dalam pengisian instrument.

\section{SIMPULAN}

Kinerja kepala sekolah yang baik apabila bisa menerapkan standar penilaian dengan baik. Sebagai kepala sekolah bisa memberikan contoh kepada guru. Hasil yang diperoleh dalam penelitian dapat dikatakan baik berdasarkan dengan kepampuan setiap responden dalam mensikapi kegiatan yang ada sesuai dengan istrumen yang ada. Dengan demikian bahwa kegiatan kepala sekolah dalam penialian kinerjanya bisa dijadikan contoh bagi guru di setiap sekolah.

Kinerja guru bisa diangap baik apabila memenuhi 4 kriteria yaitu pedagogik, kepribadian, sosial, dan professional. Dengan semuanya itu dilaksanakan guru dapat diangap bisa bekerja dengan baik. Setiap guru memiliki karakteristik dan kemampuan masing-masing, jadi tidak bisa diterapkan semua guru harus memiliki kemampuan yang sama. Berdasarkan analisis yang dilakukan diperoleh keberagaman guru dalam melaksnakan kegiatan dan dari situ dapat diambil kesimpulan bahwa guru sangatlah beranaka raga.

Kepala sekolah dengan guru di Kecamatan Tempel berdasarkan dengan analisis di atas bahwa penilaian kinerja kepala sekolah dan penilaian kinerja guru tidak ada keterkaitannya namun saking melengkapi. Menurut penjelasan dan analisis dari supervisi kepala sekolah diperoleh data dengan kategori baik dalam penyelenggaraan supervisi. Penilaian kinerja kepala sekolah dan penilaian kinerja guru muhammadiyah Kecamatan Tempel berdasarkan dengan data analisis yang sudah di sampaikan bahwa Sig (2-tailed) antara keduanya lebih besar dari 0.05 , dan dinyatakan tidak adanya keterkaitan antara keduanya.

Secara keseluruhan kinerja guru dan kepala sekolah sangatlah penting untuk membangun sekolah walaupun dalam penilaianya tidak ada keterkaitanya. Dengan adanya kinerja dapat diperoleh dan diketahui kemampuan baik guru maupun kepala sekolah. 
Kinerja kepala sekolah akan berdampak pada kinerja guru dan sebaliknya. Sehingga kedua kinerja tersebut dapat meningkatkan kualitas sekolah. Jadi keseluruhan kinerja saling beriringan dan berkesinambungan untuk saling melengkapi.

\section{SARAN}

Berdasarkan dengan hasil penelitan, ada beberapa hal yang dapat diangkat sebagai bahan koreksi buat kepala sekolah dan guru, serta dapat dijadikan bahan pertimbangan bagi peneliti yang akan datang.

Bagi kepala sekolah dan guru di Kecamatan Tempel hendaknya untuk melaksanakan kegiatan kinerja kepala sekolah dengan baik secara terencana dan terdokumentasi. Pelaksanan supervisi guru diharapkan dilaksanakan dengan pembuatan program kerja dan dilaksanakan dengan baik. Sebagai guru hendaknya bisa melaksanakan kegiatan supervisi dan dilaksanakan dengan baik, bukan hanya sekedar dokumen namun sebagai penyemangat diri untuk menjadi lebih baik.

Bagi pembaca yang ingin melakukan penelitian di sekolah Muhammadiyah di Kecamatan Tempel hendanya bisa menjadi bahan pertimbangan sebagai dasar pententu penelitian yang lebih baik lagi menggunakan tinjauan yang berbeda atau memperdalam lagi penelitian ini.

\section{DAFTAR PUSTAKA}

Abbas. (2017). Penilaian Kinerja Kepala Sekolah. Journal: Didaktika Jurnal Kependidikan, Jurusan Tarbiyah STAIN Watampone, Vol. 11 No. 1, Juni 2017. ISSN: 1978-0214 hal 12-19.

Afifah, N (2019). Hubungan antara Kepemimpinan Kepala Sekolah dan Kinerja Guru di Sekolah Menengah Kejuruan Muhammadiyah 2 Pekanbaru., repository.uinsuska.ac.id, http://repository.uin-suska.ac.id/22995/

Ahmadi. (2010). Pengembangan Kinerja Kepala Sekolah (Studi Tentang Pengaruh Diklat Dan Kompetensi Kepala Sekolah Terhadap Kinerja Kepala Sekolah Dasar) Di Kabupaten Natuna Provinsi Kepulauan Riau. (Tesis)Sekolah Pascasarjana, Universitas Pendidikan Indonesia, Bandung.

Ali, S, \& Hasanah, E (2021). Kepemimpinan Kepala Sekolah dalam Menjamin Mutu Pendidikan Pada Masa Pandemi Covid-19 di SMA Muhammadiyah 3 Yogyakarta. Jurnal Ilmiah Mandala Education, ejournal.mandalanursa.org, http://ejournal.mandalanursa.org/index.php/JIME/article/view/1735

Alwildayanto, A. (2014). Kepemimpinan Pendidikan dalam Pengembangan Budaya Mutu (Principal Leadership Quality Culture). Yogyakarta: DeePublish. 
Anggini, Y Mudi, \& Suwarno, MP (2018). Kepemimpinan Kepala Sekolah Dalam Pembinaan Kinerja Guru di SD Birrul Walidain Muhammadiyah Sragen., eprints.ums.ac.id, http://eprints.ums.ac.id/id/eprint/68438

Ari Bowo, A. (2015). PENGEMBANGAN PENGELOLAAN PEMBELAJARAN EKONOMI BERBASIS LINGKUNGAN DENGAN STRATEGI SMALL GRAUP DISCUSSION DI SMA MUHAMMADIYAH 1 SURAKARTA. Academy of Education Journal, 6(1). https://doi.org/10.47200/aoej.v6i1.124

Ariyadi, D, \& Rohmah, W (2019). Strategi Kepala Sekolah dan Kinerja Guru dalam Meningkatkan Kualitas Sekolah di SMA Muhammadiyah 2 Surakarta Tahun 2018., eprints.ums.ac.id, http://eprints.ums.ac.id/id/eprint/77798

Djadmiko, Eko. (2006). "Pengaruh Kepemimpinan Kepala Sekolah dan Sarana Prasarana Terhadap Kinerja Guru SMP Negeri Kota Semarang" Jurnal Fokus Ekonomi Vol. 1 No. 2 Desember 2006 : 19 - 30.

Djafar, H, \& Nurhafizah, N (2018). Pengaruh Motivasi Kepala Sekolah Terhadap Kinerja Guru Dan Pegawai Di SMK MUHAMMADIYAH 3 MAKASSAR. Idaarah: Jurnal Manajemen $\quad$..., journal.uin-alauddin.ac.id, $\quad \underline{\text { http://journal.uin- }}$ alauddin.ac.id/index.php/idaarah/article/view/5064

Dwikoranto, D (2018). PENINGKATAN KINERJA GURU DALAM PROSES PEMBELAJARAN MELALUI SUPERVISI AKADEMIK DI SMK MUHAMMADIYAH 2 YOGYAKARTA. ... : Jurnal Penelitian dan Kajian Pendidikan Islam, tajdidukasi.or.id, https://tajdidukasi.or.id/index.php/tajdidukasi/article/view/100

Elger, D. (2007). Theory of Performance. Faculty Develpment Series.

Firman, F, \& Pitaloka, K (2021). PENGARUH GAYA KEPEMIMPINAN KEPALA SEKOLAH TERHADAP KINERJA GURU SMP MUHAMMADIYAH I JOMBANG. Jurnal Pedagogi: Jurnal Penelitian dan ..., jurnalpedagogi.org, https://www.jurnalpedagogi.org/index.php/pedagogi/article/view/50

Hartanto, S, \& Sumardjoko, B (2018). PENGELOLAAN PENILAIAN KINERJA GURU DI SMK MUHAMMADIYAH 4 SURAKARTA., eprints.ums.ac.id, http://eprints.ums.ac.id/id/eprint/62395

Karwanto, K Kepemimpinan Pembelajaran Kepala Sekolah Dalam Meningkatkan Kinerja Guru di SMP Muhammadiyah 3 Waru Sidoarjo. ejournal.unesa.ac.id, https://ejournal.unesa.ac.id/index.php/inspirasi-manajemenpendidikan/article/view/37588

Kemendiknas. (2010). Pedoman Pelaksanaan Penilaian Kinerja Guru ( PK Guru ).

Keputusan bersama Mendikbud dan Kepala BAKN Nomor : 0433/P/1993 dan Nomor 25 Tahun 1993.

Lailatussaadah. (2015). Upaya Peningkatan Kinerja Guru. Journal: Dosen Fakultas Tarbiyah dan Keguruan UIN Ar-Raniry: Intelektualita- Volume 3 Nomor 1, JanuariJuni. hal 16-25.

Mangkunegara, Anwar. 2007. Manajemen Sumber Daya Manusia. Bandung: Remaja Rosdakarya.

Menteri Pendidikan Nasional. (2005).Undang-Undang No 14 Tahun 2005 Tentang Guru dan Dosen. 
Menteri Pendidikan Nasional. (2010). Peraturan Menteri Pendidikan Nasional Nomor 28 Tahun 2010 Pasal 12 tentang Penugasan Guru sebagai Kepala Sekolah/Madrasah.

Moeheriono. (2012). Pengukuran Kinerja Berbasis Kompetensi. Jakarta: Raja Grafindo Persada.

Mujib, Z (2019). ANALISIS KINERJA KEPALA SEKOLAH PROFESIONAL DI SDN SOKARAME PASESER III NONGGUNONG SUMENEP., eprints.umm.ac.id, https://eprints.umm.ac.id/57009/

Nisda, N (2019). PENGARUH KINERJA KEPALA SEKOLAH TERHADAP KINERJA GURU MADRASAH ALIYAH NEGERI (MAN) LUWU UTARA., repository.iainpalopo.ac.id, http://repository.iainpalopo.ac.id/id/eprint/3355/1/SKRIPSI\%20NISDA.pdf

Nuryati, N., Budiutomo, T., \& Bowo, A. N. (2017). PENGEMBANGAN MODEL PEMBELAJARAN PPKn ANTI KORUPSI BERBASIS LINGKUNGAN MELALUI COOPERATIVE LEARNING DI SMA/SMK SWASTA KULON PROGO YOGYAKARTA. Academy of Education Journal, 8(1), 27-49. https://doi.org/10.47200/aoej.v8i1.333

Ofintan, D, \& Harsono, SU (2020). Pengaruh Persepsi Kepemimpinan Kepala Sekolah Dan Komunikasi Internal Terhadap Kinerja Guru SMA Muhammadiyah SeBanjarsari Surakarta., eprints.ums.ac.id, http://eprints.ums.ac.id/id/eprint/80164

Oktafiani, A, \& Harsono, SU (2019). Kesulitan Kenaikan Pangkat Guru Akuntansi di SMK Muhammadiyah 1 Sragen., eprints.ums.ac.id, http://eprints.ums.ac.id/id/eprint/73505

Paiman, P., \& Temu, T. (2013). TANGGUNG JAWAB DAN KINERJA PESERTA DIDIK DALAM MENGERJAKAN PEKERJAAN RUMAH MATA PELAJARAN PENDIDIKAN KEWARGANEGARAAN DI SD MUHAMMADIYAHWIROBRAJAN II YOGYAKARTA. Academy of Education Journal, 4(1). https://doi.org/10.47200/aoej.v4i1.95

Puspita, A, \& Hamid, S (2021). Analisis Kinerja Kepala Sekolah Terhadap Motivasi Dan Kepuasan Kinerja Guru SD Di Kecamatan Curio Kabupaten Enrekang. Bosowa Journal of Education, journal.unibos.ac.id, https://journal.unibos.ac.id/jpe/article/view/654

Rafid, R (2019). KINERJA KEPALA SEKOLAH DALAM MENINGKATKAN MUTU TENAGA PENDIDIK DI SMA NEGERI 1 LATAMBAGA KABUPATEN KOLAKA SULAWESI TENGGARA., eprints.umm.ac.id, https://eprints.umm.ac.id/57187/

Sedarmayanti. (2013). Membangun Dan Mengembangkan Kepemimpinan Serta Meningkatkan Kinerja Untuk Meraih Keberhasilan. Rafika Aditama.

Septian, S, \& Sumardjoko, B (2021). Kinerja Kepala Sekolah Dalam Meningkatkan Mutu Pembelajaran Berdasarkan Tugas Pokok Kepala Sekolah Di SMP Muhammadiyah 7 Banyudondo (Studi Kasus di ..., eprints.ums.ac.id, http://eprints.ums.ac.id/id/eprint/91656

Sugito, G (2020). Pengaruh Kepemimpinan dan Motivasi Kepala sekolah terhadap Kinerja Guru SMP Muhammadiyah Purwokerto., repository.iainpurwokerto.ac.id, http://repository.iainpurwokerto.ac.id/id/eprint/7361

Sugiyono. (2016). Metode Penelitian Manajemen. Bandung: Alfabeta. 
Suharsimi, A. (2012). Dasar-dasar Evaluasi Pendidikan. Jakarta: Bumi Aksara.

Tarmo, T, \& Sumardjoko, B (2019). Penilaian Kinerja Guru Di SMK Muhammadiyah 3 Surakarta., eprints.ums.ac.id, http://eprints.ums.ac.id/id/eprint/77939 